\title{
Characteristics of the Botswana Press
}

\author{
Richard Rooney
}

There are serious deficiencies in our knowledge of the press in Botswana in terms of its political economy, the professional practices of its journalists, and the editorial content of newspapers. This paper analyses the newspapers in Botswana. It begins with a general overview of Botswana and maps the newspaper landscape in the country. It then sets out some of the key characteristics of the press in Botswana by answering three research questions. (i) What are the characteristics of the editorial content in Botswana newspapers? (ii) How does the state-controlled Daily News impact on the newspaper market generally? (iii) What are the capacities of journalists in Botswana and where might there be areas for improvement?

The paper utilizes a content analysis of the editorials of the country's newspapers identifying the main news agendas and also the sources of information that journalists rely on for their reports.

It concludes that the Daily News distorts the newspaper market and undermines the private press; that there is a diverse private press, but that all newspapers rely on powerful voices for their editorial content to the exclusion of ordinary people; and that while there are many attributes of the press to admire, there is a need for the capabilities of journalists to be improved.

\section{Keywords:}

Botswana, Daily News, private and public press, journalistic skills

\section{Introduction}

There are serious deficiencies in our knowledge of the press in Botswana, in terms of its political economy, the professional practices of its journalists and the editorial content of newspapers. It is even difficult to get reliable information about newspaper circulations because so few are independently audited.

This paper goes a small way to rectifying the situation by offering an overview of the newspaper sector in Botswana. The press market in Botswana is distorted by the domination of the state-controlled Daily News, even though there are 14 privately-owned newspapers 
(mostly published weekly) circulating in the country. Government over the past 10 years has allowed human and material resources at the Daily News to be subsidised, so that it does not have normal overheads. Advertising rates are also kept artificially low in an attempt to undermine competitors' ability to accrue revenue and this undermines profitability. These actions have weakened the stability of the newspaper sector in Botswana and given the government an influence that extends far beyond the rigid control of its own media.

The paper begins with a general overview of Botswana and maps the newspaper landscape in the country. It then sets out some of the key characteristics of the press in Botswana by answering three research questions. (i) What are the characteristics of the editorial content in Botswana newspapers? (ii) How does the state-controlled Daily News impact on the newspaper market generally? (iii) What are the capacities of journalists in Botswana and where might there be areas for improvement?

The paper draws on a content analysis of newspapers in Botswana conducted in 2011, identifying the main news agendas for private newspapers in Botswana and also the main sources of information that journalists use.

\section{Country Profile}

Botswana is a landlocked country in southern Africa roughly the size of Texas or France with a population estimated at 2,065,398 with a stable democratic, parliamentary government and a stable economy (Department of State, 2011a).

Since independence from Britain in 1966, Botswana has had uninterrupted civilian leadership, progressive social policies, and significant capital investment creating one of the most dynamic economies in Africa (CIA, 2011). This relative wealth has allowed for conditions to exist that can support a private media industry through advertising.

Free and fair elections are held regularly and the constitution provides for fundamental rights and freedoms. The political scene is stable and the Botswana Democratic Party (BDP) has been in power since the first elections were held on the eve of independence from Britain (World Bank, 2011). This political stability allows a free media to exist relatively unhindered and as Fombad (2011, p.16) points out, Botswana showed a commitment to freedom of the 
mass media by not clamping down on them, like most African countries did, after its independence.

The literacy level (defined as those aged over 15 who can read and write) is high in Botswana at 81.2 percent of the total population (CIA, 2011) affording a large potential market for newspapers in the country.

\section{Press Landscape}

The media landscape is dominated by government-controlled media in both print and broadcasting, but there are significant numbers of private media, especially in the print sector, with a reasonable degree of diversity and independence (Fombad, 2011, p.18).

In the broadcasting sector, there are two state-owned national radio stations, three national privately owned and eight foreign stations in Botswana, along with one state-owned and three privately owned television stations (IREX, 2010).

In Botswana, some newspaper titles although nominally published weekly do not always appear and some quietly close down completely. Because of this it can be difficult for the researcher to ascertain the continuing existence of titles, and the only way to be sure which titles are still in circulation is to find them on the newsstands. With that in mind, we can conclude that at the time of writing there is only one daily newspaper, the state-owned Daily News published Monday to Friday.

All newspapers, except the Daily News, are privately-owned. Mmegi, is published Tuesday to Friday and its companion, The Monitor, is published on Monday. The rest of the newspapers publish weekly. They are The Botswana Gazette, The Botswana Guardian, The Echo, The Global Post, The Midweek Sun, The Mirror, The Monitor, Ngami Times, Sunday Standard, Sunday Tribune, The Telegraph, The Voice and The Weekend Post.

There is no regulation of media ownership and in the private media there is some concentration: the Dikgang Publishing Company has the sole ownership of the Botswana Guardian, Midweek Sun, Mmegi and The Monitor. However, the Media Practitioners Act of 2008, that has yet to be implemented, does allow for a Media Council to determine if there are anti-competitive acts within the media sector (MISA, 2009, p. 32). 
It is difficult to get reliable information about newspaper circulations in Botswana because so few are independently audited, but Mogalakwe and Sebudubudu (2006) estimated there were 573,000 copies of newspapers circulating in Botswana every week. Six newspapers in Botswana do have their circulations independently verified by the Audit Bureau of Circulations (ABC) in South Africa, as set out in table 1.

Table 1

Circulations of the Six Newspapers Independently Audited by the Audit Bureau of Circulation, South Africa

July - September 2011 and July - September 2010

\begin{tabular}{|c|c|c|c|c|}
\hline Title & $\begin{array}{c}\text { Circulation July - } \\
\text { September 2011 }\end{array}$ & $\begin{array}{c}\text { Circulation July - } \\
\text { September 2010 }\end{array}$ & $\begin{array}{c}\text { Decline Year } \\
\text { on Year }\end{array}$ & $\begin{array}{c}\text { Percentage } \\
\text { Decline }\end{array}$ \\
\hline $\begin{array}{c}\text { Botswana } \\
\text { Gazette }\end{array}$ & 21,621 & 25,942 & 4,321 & 16.7 \\
\hline $\begin{array}{c}\text { Botswana } \\
\text { Guardian }\end{array}$ & 20,796 & 21,661 & 865 & 4.0 \\
\hline Midweek Sun & 16,957 & 17,865 & 908 & 5.0 \\
\hline Mmegi & 11,242 & 13,660 & 2,418 & 17.8 \\
\hline Monitor & 15,015 & 17,784 & 2,769 & 15.6 \\
\hline Voice & 26,794 & 27,336 & 542 & 2.0 \\
\hline
\end{tabular}

Source: Audit Bureau of Circulation South Africa 2011

Information about circulations of the other newspapers in Botswana is not easy to obtain. However, the following estimates of print runs are in the public domain: The Daily News, 65,000 copies (Fombad, 2011, p. 20); Sunday Tribune, 8,000 (MISA, 2009, p. 26); Echo, 15,000; Sunday Standard, 22,000; Telegraph, 9,000 (Motsela, 2010, p. 8); Ngami Times, 10,000 (Fombad, 2011). The Weekend Post states on its own website that it prints 10,000 copies per edition, but hopes to double this (Weekend Post, n.d.). 
Some newspapers have websites which publish a selection of the editorial material from the main print edition. They are The Botswana Gazette, The Botswana Guardian, The Echo, The Sunday Standard, The Weekend Post, and The Ngami Times. Mmgei and The Monitor have a combined website. In all cases, no information is available about the number of site visits, but one might assume the number to be relatively small since the estimated number of Internet users in Botswana is only 120,000 (CIA, 2011), and the Internet is not available across the whole country, especially in remote rural areas where there is no electricity (Fombad, 2011, p.19).

The ABC figures in Table 1 show a decline in circulation year on year for all titles, but this decline is not uniform in size. Insufficient evidence is available to account for these declines, but they are not unusual in the context of newspaper circulation in neighbouring South Africa and the wider region generally, where circulations are falling in all sectors of the newspaper market, even though not all titles are necessarily affected in the same way.

Private newspapers are centred on Botswana's capital, Gaborone, and distribution to other parts of the country is problematic. Access to print media in rural areas is a challenge in a country with a population of 2 million people living in 600,370 sq. km, a country the size of France. As a consequence, Botswana media share the same basic characteristics with those of many other African states, including skewed, urban-based centralisation of infrastructure, resources and audiences. Community media in Botswana is a particularly weak area (Zaffico 1993; Kabeta \& Ndlovu 2009).

Costs of distribution across the entire country are high and private newspaper companies either distribute the papers themselves or use a variety of means such as subscriptions, courier and public transport, which are not very efficient (Fombad 2011; MISA 2009, p.27).

\section{The Characteristics of the Editorial Content in Botswana Newspapers}

Content analysis of the editorial content of newspapers in Botswana in 2011conducted by the present writer suggests that the newspapers cater for a wide range of readership needs, from the overtly serious to the decidedly non-serious. 
Although there is no readership research available - neither marketing nor academic - to confirm this, it would appear that the Botswana press follow the same patterns as newspapers in other countries with large press markets, by differentiating the market according to the demographics of the general population. So the serious newspapers appeal to people with high levels of formal education and those who are in (or aspire to) managerial or professional occupations. This can be seen in both the editorial and advertising content. Articles in the serious newspapers often exceed 1,000 words, and use specialised language. Comment articles in particular are written by experts in their fields and appear to be addressing other experts. This is especially so in the area of education, business and politics.

Classified advertising for job vacancies in the serious press concentrates on jobs in the professions or government that require applicants to have high academic qualifications and offer above average salaries. In the context of the Botswana press, The Sunday Standard and The Weekend Post are the two titles that make up the "serious" market. At the other end of the continuum is the tabloid market. Here, "tabloid" refers to more than just the size of the newspaper page. Tabloid newspapers tend to pay little attention to politics, economics and public-sphere material, concentrating instead on sensation, human interest, sport and entertainment. They also tend to give prominence to the coverage of scandals and misconduct. More space is devoted to headlines and visuals than to text (Rooney, 1998).

In Botswana, the tabloid newspapers seem to appeal to people who have less formal education. The newspapers rely on large headlines, illustrations and short articles, mostly with fewer than 300 words. Short sentences and short paragraphs are used, with typographical devices such as some words capitalised or printed in bold type to add emphasis. The articles tend to appeal more to readers' sensations than to their intellects, and there are very few that require them to have prior knowledge of the subject under discussion. Advertisements in the tabloid press are mainly for mass consumption goods that might appeal to people regardless of their education or occupational backgrounds, such as mobile phone accounts and supermarkets.

Two titles, The Voice and The Midweek Sun, constitute the most "tabloid" or non-serious of the market. They carry huge headlines and pictures and very little text. The Voice is the only newspaper in Botswana to publish "pin-up" pictures of scantily clad women. 
The other titles - all tabloid in size - could be plotted on the continuum somewhere between the "serious" and the "tabloid". They are known in some countries, for example the United Kingdom or the United States, as the "mid-market" (Rooney, 2010). This is because, while they share many of the attributes of the "tabloid" press, especially in the desire to be entertaining, they also contain more serious material than the tabloids, but less than the overtly "serious" newspapers.

In Botswana, readers of the mid-market newspapers would be expected to have moderately high levels of educational attainment to read and understand the articles, but they would probably not need to have been educated to tertiary level. Some articles run to several hundred words, with the occasional ones exceeding 1,000 words. The editorial content is varied and would include some items that are clearly "tabloid" in style and speak to the senses rather than the intellect, but there are also a number (but not the majority) that are written with expertise and might require readers to have prior knowledge of the subject under discussion. Advertisements in these newspapers, as with tabloids, are for mass consumption goods, but there are some adverts, such as those for courses being run at tertiary colleges, that would not appear in the tabloids. Newspaper titles that would be in this "mid-market" include The Botswana Guardian, The Botswana Gazette, The Echo, The Global Post, Mmegi, The Monitor and The Telegraph.

The content analysis looked at nine of the privately-owned newspapers in Botswana and examined all the editorials in them, which for the purpose of this research means all material that was not advertising. This included news stories, feature articles and photographs, and also material that may not have any news value at all (e.g. cartoons and horoscopes).

Five copies of each weekly newspaper selected at random during the fourth quarter of 2011were examined. The types of editorial were grouped together into categories, a process which was simplified because most newspapers give labels to every editorial page (e.g. news, business, entertainment, sport, etc.), and these labels were used for the content count. Where a page has editorial, it is counted as a whole page irrespective of the amount of advertising that appears on it. There were neither national events nor major incidents that might have attracted disproportionate coverage in the newspapers to distort the findings. 
Table 2 is a snapshot of this research, showing the results for The Weekend Post (a serious newspaper), The Botswana Guardian (a mid-market title), and The Voice (a tabloid). The Weekend Post is a "Berliner" sized newspaper (a little smaller than a broadsheet). The other two are tabloid size.

Table 2

Editorial Content of Botswana Press

\begin{tabular}{|c|c|c|c|}
\hline & Weekend Post & Botswana Guardian & The Voice \\
\hline Total Pages & 144 (Berliner) & 256 (Tabloid) & 252 (Tabloid) \\
\hline Full Page Adverts & $29(20.1)$ & $82(32.0)$ & $71(28.2)$ \\
\hline Business & $18(12.5)$ & 35 (13.7) & $30(11.9)$ \\
\hline Community / Local & Nil & $18(7.0)$ & Nil \\
\hline Fashion & $3(2.1)$ & Nil & $5(2.0)$ \\
\hline Features & $2(1.4)$ & $11(4.4)$ & $21(8.3)$ \\
\hline Foreign & $2(1.4)$ & $6(2.3)$ & $3(1.2)$ \\
\hline 'Good News' & $\mathrm{Nil}$ & Nil & $1(0.4)$ \\
\hline Leisure & $8(5.6)$ & $25(9.8)$ & $38(15.1)$ \\
\hline $\begin{array}{c}\text { Letters to the } \\
\text { Editor }\end{array}$ & $5(3.5)$ & $4(1.6)$ & Nil \\
\hline Motoring & $4(2.8)$ & Nil & Nil \\
\hline News & $22(15.2)$ & $36(14.0)$ & $50(19.8)$ \\
\hline Opinion & $33(23.0)$ & $21(8.2)$ & $10(4.0)$ \\
\hline Religion & $5(3.5)$ & Nil & Nil \\
\hline Sport & $13(9.0)$ & $18(7.0)$ & $18(7.1)$ \\
\hline Travel & Nil & Nil & $5(2.0)$ \\
\hline
\end{tabular}

The table above represents editorial content analysis of three privately-owned newspapers, counting the number of pages devoted to editorial categories. The figures in brackets are percentages of the total newspaper.

The three selected newspapers in Table 1 are not dissimilar from newspapers as a whole in Botswana. Although there is a wide range of types of newspaper available, all the titles have 
certain characteristics in common. All, for example, devote considerable space to the coverage of sport - ranging from 7 percent to 16 percent of editorial space. All newspapers, even the tabloid Voice and Midweek Sun, have editorial sections given over to finance (in the case of the tabloids this tends to concentrate more on personal finance). The Sunday Standard devotes 20 percent of editorial space to this category.

Articles, clearly identified as opinion pieces, are common to all the newspapers, with the Weekend Post devoting the most space to this (23\%) and The Voice the least (4\%). The Weekend Post runs both clearly identified opinion pieces and news features that are analytical and in some cases are polemical, but not labelled as such. "Opinion" in The Voice tends to be less overtly about public sphere matters and more about advice on personal and private matters readers may have raised with the newspaper.

Editorial matter on leisure and entertainment is important to all types of newspaper ranging between 5.6 and 15.1 percent of editorial space. The Weekend Post has the lowest coverage and The Voice and The Midweek Sun jointly the highest.

Hardly any news from outside Botswana appears in the newspapers - serious or non-serious. What foreign news there is tends to be from elsewhere in the continent of Africa. The Botswana newspapers do not have their own foreign correspondents and rely on material from news agencies. Botswana is not alone in this. A content analysis of newspapers in Swaziland, another southern African nation, revealed a similar trend (Rooney, 2007).

In the final week of the survey, The Voice devoted a page to what it labelled "good news", although what made "good news" was left vague by the newspaper. The Voice intended to make this a regular feature in the newspaper.

The content analysis also examined the main source in the lead news items on each of the main news pages (front, three, five and seven). This was relatively simple as in Botswana newspapers journalists tend only to rely on one source per article. Some of these pages had no editorial matter as they consisted of full page advertisements. Editorial articles originated mostly from government, parliament and political parties in most newspapers. The main exception to this was The Voice which had no articles from the government or parliament and only 9.1 percent of editorial space given to political parties. 
Table 3

Sources Editorial Items in Three of Botswana's Privately-owned Newspapers

\begin{tabular}{|c|c|c|c|}
\hline $\begin{array}{l}\text { Total Editorial } \\
\text { Items }\end{array}$ & Weekend Post & Botswana Guardian & The Voice \\
\hline & 47 & 31 & 33 \\
\hline Business & $5(10.7)$ & $9(29.0)$ & $4(12.1)$ \\
\hline Government & $12(25.6)$ & $5(16.1)$ & Nil \\
\hline International & $2(4.3)$ & $2(6.5)$ & $4(12.1)$ \\
\hline Law Courts & $5(10.7)$ & $2(6.5)$ & $4(12.1)$ \\
\hline Locally-based & $3(6.4)$ & $3(9.7)$ & $3(9.1)$ \\
\hline Contacts & & & Nil \\
\hline Parliament & $1(2.1)$ & Nil & Nil \\
\hline Political Parties & Nil & $5(16.1)$ & $15(45.5)$ \\
\hline Trade Unions & $2(4.3)$ & $4(13.0)$ & $1(3.3)$ \\
\hline All Other Sources & $27(35.9)$ & & \\
\hline
\end{tabular}

The above table shows the results for The Weekend Post, Botswana Guardian and The Voice. The figures in brackets represent percentages of the total number of editorial items counted.

The sources of the majority of news reports in the newspapers are organized events, such as parliamentary sittings and staged events (public conferences and conventions), to which the media are invited, and press statements. There are very few stories about ordinary people. This raises questions about the way the political class dominates and who else within Botswana is allowed to communicate through the news media. There are some exceptions to this: locally based stories of human interest appear to have come from local sources rather than having been fed to reporters by the police or emergency services.

The police and emergency services in Botswana do not appear to be significant sources of editorial material. Only the Sunday Standard published more than one article sourced from the police (six) and two titles (Botswana Guardian and The Echo) had no such items at all. 
The result for The Voice newspaper is distorted because its main item on page three in each edition was a pin-up picture - accounting for 24.2 percent of total editorial space in the survey.

The content analysis broadly supports previously published commentary on newspapers in Botswana that suggests newspapers in Botswana emphasise coverage and news selection on official speeches, the comings and goings, and the images of top national political leaders, particularly the President. Coverage in state media is structured to ensure a top-down communications flow with a susceptibility to monopolisation and political manipulation at the top. Thus, the media is perpetuating social divisions in the country by not including the voices of people across all social strata (Fombad 2002, p. 662; MISA 2009, p. 36; Merrill 1987, quoted in Zaffiro 1993, pp. 87-102).

The private media tend to support opposition political parties and are mostly event driven, but even the private media tend to give most space to leaders' voices with the voices of ordinary Botswana hardly being represented by the state or private media (MISA, 2011). Coverage of politics is unbalanced. The state press and broadcast media cover only one political party, the ruling $\mathrm{BDP}$, while there is a perception that the private media focus more on the opposition parties and are sometimes seen as opposition to the government.

Newspapers are "personality driven". Because of the limited resources available to the media, high-profile personalities or events get more coverage. "Developmental" stories are covered well by the government media, but not by the private media, often because these journalists lack information about government activities and do not know what the state's intentions are (MISA 2009; MISA 2011).

Newspapers tend to shun controversy and generally there is no depth in reporting and no newspaper has a dedicated investigation desk. Newspapers prefer simpler and safer forms of journalism like reporting on ministerial speeches (Fombad 2002, p. 662; Merrill 1987, quoted in Zaffiro 1993, pp. 87-102, MISA 2009, p.58; MISA 2011, p. 54).

Most newspapers (public and private) are criticised for being elitist and not fairly reflecting all the voices in society because they only publish in the English language (MISA 2009, p.8; Sechele 2006, p. 30; MISA 2011, p. 31) even when, according to the 2001 census, Setswana 
is spoken as a first language by 78.2 percent of people, Kalanga (7.9 percent), Sekgalagadi (2.8 percent), official English (2.1 percent), other (8.6 percent), and unspecified (0.4 percent) (CIA, 2011). The Daily News and Mmegi do, however, carry Setswana inserts (Sechele, 2006, p. 30).

\section{How the State-controlled Daily News Distorts the Newspapers}

The Daily News comes under the Office of the President along with state broadcasting outlets Radio Botswana and Botswana TV. Government media employees are employed under the Public Service Act, so they cannot publish information without the permission of the permanent secretary or the ministry (MISA, 2011, p.18). In general, the government's position is that official media purveys official information; therefore, journalists who work for them are civil servants and are controlled by civil service conventions. They are free to report anything they want as long as they toe the official line (Fombad, 2002).

For almost 15 years after independence in 1966, state media operated without much challenge. Three newspapers were created in 1967, 1968 and 1972, but none lasted beyond 1973 (Nyamnjo, 2002, p.757). The brief existence of these newspapers (until 1973) offered competition to the state media but hardly any challenge to government for although supposedly commercially and politically independent ,"all three exhibited loyalty and sympathy towards the government of the day as well as the absence of crystal clear, stable and easily discernible editorial policies" (Rantao 1996, quoted in Nyamnjo, 2002, p.757).

Several newspapers emerged during the 1980s, primarily as a consequence of economic growth in Botswana that saw it upgraded from a low-income to middle-income country. Five newspapers launched during this period: The Botswana Guardian (1982), The Examiner (1982), Mmegi wa DiKang (1985), The Botswana Gazette (1985) and The Midweek Sun (1989). These were followed by The Francistowner (now known as The Voice) launched in 1992 and The Mirror in 1995 (Mogalakwe \& Sebudubudu, 2006). 
Today, it is widely recognised that the Daily News and the state-owned broadcasting outlets' mandates are to promote government policy, and they are censored by the government so that they provide inadequate access to the political opposition parties and government critics. Furthermore, it is recognised that the government sometimes censored or otherwise restricted news sources or stories that it found undesirable (Fombad 2002; Fombad 2011; Freedom House 2011; Mogalakwe \& Sebudubudu 2006).

In 1989, the minister with responsibility for information and broadcasting warned government journalists that Radio Botswana and The Daily News could not operate like the private media since they were vehicles through which the government of the day communicated with the people that brought it to power (Fombad, 2002).

The government directly interferes in the editorial content of The Daily News. For example, in 2011 an article about the Botswana government giving P1 million to Japan, following its devastating tsunami in March 2011, was withdrawn from The Daily News by "higher authorities" as it was felt this would not be welcomed during the then on-going public workers' strike (MISA, 2011, p. 29). The public workers' strike itself offered a further example of what the Media Institute for Southern Africa (MISA) called "unbalanced or propagandist reporting," where government-controlled media reflected only government voices (MISA, 2011, pp. 33-34).

As well as controlling the news content of its media, the government has put considerable resources into The Daily News, thus crowding out and stifling the independent press (Mogalakwe, 2006). The Daily News distorts the newspaper market by competing directly with the private sector and, as Mogalakwe (2006) observed, independent newspapers are "no match for the massive human and material resources and logistical capacity available to the government-owned newspaper." The biggest competitive advantage that The Daily News has is that it does not have normal overheads, since all these are taken care of from government funds. It also receives hidden government subsidies because it is delivered by government land and air transport as a matter of policy (Zaffiro, 1993).

Unlike private newspapers, The Daily News is delivered to most areas of Botswana, and in rural areas it is often the only print media available. This makes it in effect Botswana's only national newspaper, covering almost the whole country through a network of bureaux and 
correspondents operating under the government-owned and controlled Botswana Press Agency (BOPA) (MISA 2009, p.27; Mogalakwe 2006).

This and the fact that the newspaper is given away free of charge helps to make The Daily News the most widely read newspaper in Botswana and arguably the most influential. There is some belief that because it is owned by the government it is regarded as reliable because any information that comes from the government is believed to be accurate (Mogalakwe, 2006).

The strategy for The Daily News to compete with the private media is relatively new. In 2001/ 2002, the government began a policy to "commercialise" The Daily News - in effect embarking on aggressive marketing to take advertising revenue away from the independent press. Since 2003, when The Daily News began to compete with private newspapers, it has grown from a four-page, black-and-white daily newspaper to a paper which regularly has 32 pages, full-colour with a 60: 40 ratio of advertising to editorial.

Specifically, The Daily News competes for advertising and undercuts the rates offered by private media companies. Advertisers prefer The Daily News because they want high circulation to reach the maximum number of people (MISA 2009, p.33; Mogalakwe 2006). Government is in the unique position of being a major media player and also the largest advertiser in the country, followed by parastatals, followed by big business. In 2006, it was believed that The Daily News accounted for 80 percent of all government and 25 percent of all national expenditure on advertising (Mogalakwe, 2006). Another estimate gave The Daily News about 70 percent of the advertising market in Botswana (Anon, 2006, p.6). Sometimes private newspapers have just three main advertisers - the country's three mobile phone companies: B Mobile, Orange and Mascom (MISA, 2011, p. 36).

Cover prices are kept low because readers cannot afford to pay much and would rather spend their money on food and transport (Anon, 2006, p. 6). At an average price of P8 (US\$1.22) per newspaper, newspapers are not affordable to ordinary citizens in a country where a loaf of bread costs P7. Therefore, newspapers are reliant on advertising for their business survival (MISA, 2011, p. 7). 
This puts the private press in a perilous financial situation. In 2006, Pamela Dube, Chair of the independent Press Council of Botswana, said that most of the privately owned newspapers only had the capacity to survive for a few more years and she expected a number of them would have to close down for economic reasons (quoted in Anon, 2006, p. 6). Dube was proved right, but her timing was out a little. In the three years up to 2011, three titles closed: The Francistown Blue Jacket, The Tswana Times and The Independent Informer (MISA, 2011, p. 5).

This interference from government means that surviving as a privately owned newspaper requires resourcefulness and resilience, as it is hard to compete against the governmentsupported media, which do not rely on advertising revenue for survival and are able to offer adverts at considerably lower rates than the private media. This is aggravated by the fact that the advertising revenue is often not collected by the government media publications (MISA, 2009, p. 8).

Government is the largest employer, business entity and advertiser in Botswana, and is not averse to using its power to give the media it controls commercial advantages and in so doing to distort the newspaper market.

Government can pull advertising from newspapers it deems to be too critical of its policies, and it can coerce companies in the private sector which want to keep in its favour not to advertise. As an example, in April 2001, the Botswana government issued economic sanctions against the Botswana Guardian and its companion, The Midweek Sun, after The Guardian published a mocked up photograph critical of the Vice-President, Ian Khama. A directive was sent from the Office of the President to all ministerial departments, parastatals and private companies in which the government was a shareholder instructing them to cease advertising in the two newspapers with immediate effect (Good 2008, p. 61; MISA 2009, p.38; Mogalakwe 2006).

As part of its campaign against the two newspapers, the government sent letters to private companies telling them if they continued to advertise in The Guardian or Midweek Sun, they would be excluded from doing business with the state. The orders were later lifted after a High Court ruling against the government (Balule \& Kandjii, 2004). 
This decision was an embarrassment to the government, which decided to commercialise The Daily News and make it a rival and competitor of the independent press. It seems the 2001 High Court ruling did not stop government's attempts to bully the media as today government officials are known to approach private media with threats and to strike deals with them, and there is a continuing sense that government is subtle in its actions and the private media know that if they criticise it, they will lose out on advertising (MISA 2009; MISA 2011).

\section{The Capacities of Journalists in Botswana and the Areas for Improvement}

The results of the content analysis suggest that there are areas of improvement that journalists in Botswana could make. These mainly centre on the way they select the news agenda and the sources they use for information in articles. It appears that a disproportionate number of articles originate from government or from staged events and that the voices of ordinary Botswana are under-represented in the newspapers.

Journalists in Botswana face many obstacles in their reporting. Some are due to a scarcity of resources and some due to deliberate attempts by government officials to withhold information. Despite these obstacles, private media in Botswana are said to pursue their oversight function with determination, but it is more difficult for private media organisations than for government-owned ones to obtain access to government held information (Freedom House 2011; Motsela 2010, Department of State 2011b).

The content analysis suggests that journalists often over-rely on powerful sources for information and this demonstrates that they often lack the capacities required in performing their duties properly, particularly when it comes to collecting information to enable them to fully explain to their readers what is going on. Media practitioners in Botswana recognise these problems. In 2009, and again in 2011, MISA held workshops with media practitioners in Botswana to collect attitudes on media performance in the country (MISA 2009; MISA 2011). Participants felt many journalists lacked sufficient knowledge and capacity and made mistakes as a result, but errors were not a result of malice.

Workshop participants reported that sometimes articles were inaccurate because it was difficult to get information, and this led to reporters relying on speculation. Each government ministry has a public information officer, but they tend to block information, rather than 
provide access to it. Participants said reporting was generally fair and was not considered to be "gutter journalism" although accuracy, fairness and balance were sometimes found to be lacking. A voluntary media code of ethics for all print media drafted by the self-regulatory Press Council of Botswana was adopted in 2004 (Press Council of Botswana, n.d.) to assist journalists in this regard.

The content analysis raised a question about the way the political class dominates as newspaper sources. One reason for this is that media houses in Botswana are generally underresourced, and privately owned newspapers in particular cannot afford to have large staffs or freelancers throughout the country. They therefore rely on contributors who know that journalists need a constant supply of material to meet their deadlines and therefore go about supplying it. Political parties in Botswana are especially aware of these needs.

The lack of resources in media houses means that most content is urban-based with rural areas in effect side-lined by the newspapers, which recognise that increasing the circulation of their newspapers where populations are so low is uneconomic, and as a result certain cultures, such as the Basarwa (San), are barely covered at all. The state-owned Daily News does better in rural areas because it can rely on the resources of the state news agency (BOPA), which has staff around the country, but they are not necessarily qualified journalists.

Workshop participants also recognised that there is a disinclination on the part of journalists to question those who hold positions of authority. Culturally, in Botswana there is a great respect for elders and most media houses are too respectful to probe into the lives of leaders unless a specific incident has come to court and is, therefore, in the public arena. Journalists also avoid reporting on subjects which offend the elders.

Improvements are unlikely to be made until the generally low status accorded to the media as a career in Botswana is lifted. The Botswana media have suffered from chronic turnover, insufficient numbers of approved posts in state-controlled media houses, and lack of trained personnel. The majority of journalists in both private and state media are secondary school graduates, young and inexperienced, with no formal media training (Zaffiro, 2000, p. 96). There is a lack of opportunities for skills upgrading (especially at educational institutions), but some organisations, for example MISA and Gender Links, run short courses and 
workshops, and the University of Botswana offers a bachelor degree in Media Studies (MISA, 2009, p. 66).

Staff numbers are low. Some small media houses have a ratio of 60 percent freelancers to 40 percent staffers. Bigger media houses have 70 percent staff to 30 percent freelancers. Private media salaries tend to be much lower than those of the state media, and an editor in the private media may earn the same salary as a junior journalist in South Africa (P15,000 per month) (Kabeta \& Ndlovu 2009, p.15; MISA 2011, p. 60).

The government media in particular suffer from debilitating staffing problems because the prospects of advancement are slim. Personnel leave as soon as something better becomes available, usually in the private sector in administration, public relations, or international organisations leaving younger inexperienced staff behind and leading to a juniorisation of newsrooms (Zaffiro, 2000, p.96). It is believed that manipulation of the system becomes the most useful skill for young journalists to learn rather than the presentation of a good news product (Molefhe 2008; Nhoma 1998, quoted in Zaffiro 2000).

\section{Concluding Remarks}

This review of newspapers in Botswana set out to ask three questions. (i) What are the characteristics of the editorial content of newspapers? (ii) How does the state-controlled Daily News impact on the newspaper market generally? (iii) What are the capacities of journalists in Botswana and where might there be areas for improvement?

The newspaper market in Botswana is large with 15 titles serving a relatively small population of 2 million people, but as businesses most of the privately owned papers are insecure. This may partly be because of the large amount of competition they face from other titles, but mostly it is because of the unfair advantage the state-controlled Daily News has in terms of resources and control over advertising.

The editorial content analysis showed that private newspapers attempt to serve the public but they are constrained by the capabilities of their journalists and by lack of resources. Although the private newspapers do not slavishly follow the government line or support the ruling 
party, they do give disproportionate space to the voices of politicians to the exclusion of ordinary people. They tend to follow a news agenda set by people in powerful positions. Vast numbers of Botswana people living in rural areas are excluded from the private newspapers because the press is urban-based (almost entirely in the capital, Gaborone) and do not have resources to efficiently distribute to rural areas. The Daily News has the advantage over the private press in this respect as it is distributed using government transport. This means that the only printed news most rural people can receive is biased towards the government.

There are a number of improvements that might be made but these are unlikely to be forthcoming as they require the government to give up its advantage over the press. Government needs to stop subsidising The Daily News and make it operate as a self-sufficient organisation. This would require it to charge market rates for its advertising and stop undercutting the private newspapers. With an even playing field, at least some of the private titles would be able to attract more advertising and thereby increase resources for editorial material and distribution. The government might also find ways of encouraging the private press through tax breaks and subsidies for distribution to rural areas. Successive governments in Botswana have boasted of the democratic credentials of the country. This would be an opportunity to demonstrate them.

Newspapers themselves need to investigate the standards of their reporting and the capabilities of their journalists. Better pay with transparent career paths from the most junior to the most senior ranks might encourage more people to stay with newspapers. This would require newspapers to invest in training. The University of Botswana already runs a bachelor degree in media studies with a pathway into journalism and is soon to launch a master's degree. The university could be utilised by the industry to help improve the levels of technical and intellectual skills, but newspapers themselves must play their part.

The Botswana government is in the best position to make most of these things happen, but it is not in its interests to act, so we should not expect change any time soon.

\section{References}

About us. The Weekend Post. Gaborone. [online]. Retrieved 20 December 2011 from 
http://www.weekendpost.co.bw/index.php?option=com_content\&view=article\&id=19 \&Itemid $=27$

Balule, B. \& Kandjii, K. 2004. Undue restriction: Laws impacting on media freedom in the SADC. Windhoek: Media Institute of Southern Africa. [online]. Retrieved 9 October 2006 from http://www.misa.org/documents/undue.pdf

Botswana. 2011. The World Fact Book. Central Intelligence Agency. [online] Retrieved 27 February 2012 from https://www.cia.gov/library/publications/the-world-factbook/geos/bc.html

Botswana. 2011a. Country specific information. Department of State, Bureau of Consular Affairs, Washington. [online]. Retrieved 27 February 2012 from http://travel.state.gov/travel/cis_pa_tw/cis/cis_1071.html

Fombad, C. 2002. The protection of freedom of expression in the public service media southern Africa: a Botswana perspective. Modern Law Review, 65(5): 649-675.

Fombad, C. 2011. Media law in Botswana. London: Kluwer Law International.

Freedom House, 2011. Report: Botswana, Freedom House, Washington. [online]. Retrieved 17 January 2012 From

http://www.freedomhouse.org/template.cfm?page=22\&country $=8002 \&$ year $=2011$

Good, K. 2008. Diamonds, dispossession and democracy in Botswana. Oxford: James Currey.

Human rights report: Botswana, 2010. Department of State, Washington. [online]

Retrieved 27 February 2012

http://www.state.gov/j/drl/rls/hrrpt/2010/af/154332.htm

Kabeta, J. \& Ndlovu, T. 2009. Botswana media sustainability index (MSI), IREX, Washington.

[online]. Retrieved 27 February 2012 from

http://www.irex.org/resource/botswana-media-sustainability-index-msi

Mogalakwe, M. \& Sebudubudu, D. 2006. State media relations. Journal of African Elections.

Special Issue: Elections and Democracy in Botswana, 5(2): 216 -220. [Mmegi Online].

Retrieved 20 February 2012 from

http://www.mmegi.bw/index.php?sid=10\&aid=3281\&dir=2010/June/Friday25

Molefhe, R. 2008. Challenges of Botswana journalism. [Mmegi Online]. Retrieved 26 August 2011 from http://www.mmegi.bw/index.php?sid=1\&aid=24\&dir=2008/July/Friday18 
Motsela, S. 2010. Botswana: National overview. This is Democracy? Windhoek.: Media Institute of Southern Africa (MISA).

MSI Botswana: Introduction-2010. Media Sustainability Index (MSI), IREX. Retrieved 19 March 2012 from http://www.irex.org/resource/botswana-media-sustainability-index-msi

Nyamnjo F. 2002. Local attitudes towards citizenship and foreigners in Botswana: An appraisal of recent press stories. Journal of Southern African Studies, 4 (4): 755 -775.

The Botswana code of ethics. 2011. Press Council of Botswana. [online]. Retrieved 22 February 2012 from http://journalism.co.za/

Report on the strengthening of Africa's media (STREAM). 28-29 June 2006. Consultative Conference. Sandton, Johannesburg. [online]. Retrieved June 242012 from http://www.uneca.org/africanmedia/documents/Report_Joburg.pdf

Rodrigo, U. \& Gunter, B. 2004. The tabloidization of British tabloids. European Journal of Communication, 19(3): 387-402.

Rooney, D. 1998. Dynamics of the British tabloid press. Javnost: The Public, 5(3): 95-107.

Rooney R. 2007. The Swazi press and its contribution to good governance. Global Media Journal, Africa edition, 1(1). Retrieved 19 March 2012 from http://globalmedia.journals.ac.za/pub/article/view/47

Rooney, R. 2010. News media and ideology in the UK. A paper presented at a lecture series organised at Girne American University, Turkish Republic of Northern Cyprus, 22 February 2010. [online]. Retrieved 25 February 2012 from

http://www.scribd.com/doc/27250311/UK-News-Media-and-Ideology-RichardRooney

Sechele, S. 2006. Africa media development initiative. Botswana Research and Findings, $\mathrm{BBC}$

World. London: Service Trust.

Southern Africa barometer, 2009. Windhoek.: Botswana. Media Institute of Southern Africa (MISA).

Southern Africa barometer, 2011. . Windhoek.: Botswana. Media Institute of Southern Africa (MISA).

Weekly newspapers summary: July 2011 - September 2011. Audit Bureau of Circulation of South Africa. [online]. Retrieved 27 February 2012 from http://cdn.bizcommunity.com/f/1111/Weekly.pdf World Bank. 2011. Botswana: Country Brief. The World Bank. Washington, DC. Retrieved 
27 February 2012 from http://go.worldbank.org/8P9IVY6270

Zaffiro, J. 1993. Mass media, politics and society in Botswana: The 1990s and beyond. Africa Today, 40(1): 7-25.

Zaffiro, J. 2000 .Broadcasting reform and democratisation in Botswana. Africa Today, 47(1): 87-102.

\section{Richard Charles Rooney}

Associate Professor, Department of Media Studies, University of Botswana

\section{Biography}

He has taught at universities in Africa, the Pacific and Europe. He published research on media and governance, media freedom, media and democracy.

Richard.Rooney@mopipi.ub.bw

Phone: (267) 3552196

Fax: (267) 3185098 